\title{
Costal Hydatid Cyst: A Rare Case Report
}

\author{
Kostal Hidatik Kist: Nadir Bir Olgu Sunumu
}

Ferdane Melike Duran', Mustafa Çalık', Saniye Göknil Çalık², Nuri Düzgün', Hıdır Esme'

\section{Abstract}

Although human beings have known of hydatid cysts for 2000 years, it is still an important public health problem even today, especially in areas where it is endemic. A 41 -year-old male patient consulted the clinic with left back pain. A thorax computed tomography image showed a cystic, expanding mass in the 9th and 10th ribs and the vertebral transverse process, with apparent destruction. Costal hydatid cyst accounts for less than $1 \%$ of all cases. There were 38 cases reported in 1978 and 60 in 2010 . Although it is endemic, there are few cases reported in our country. An unusual localization of hydatid cyst may lead to an incorrect or late diagnosis. Hydatid cyst should definitely be kept in mind in the differential diagnosis of all lesions, especially in areas where it is endemic.

Key words: Unusual localization, rib, bone, hydatid, cyst.

Hydatid disease is usually caused by the cestode Echinococcus granulosus (E. granulosus), for which humans are an intermediate host. It has been recognized since the time of Hippocrates. Cystic echinococcosis can be caused by infection with $E$. granulosus, E. alveolaris, E. multilocularis, or $E$. vogeli. It is endemic in agricultural regions and where animal breeding is prevalent, such as eastern and southern Europe, North Africa, the Middle East, the Far East, South and Central America, and the former Soviet republics, where environmental health and preventive medicine

\section{Özet}

İnsanoğlu hidatik kisti iki bin yıldır bilmesine rağmen özellikle endemik olarak bulunduğu bölgelerde bugün bile önemli bir halk sağlığı problemidir. Kırk bir yaşındaki erkek hasta sol sırt ağrısı ile kliniğimize danışıldı. Toraks BT incelemesinde 9. ve 10. kaburgalarda ve vertebra transvers procesinde kistik genişleme ve destrüksiyon gösteren kitle tespit edildi. Kostal hidatik kist tüm vakaların \%1'den azını teşkil etmektedir. Literatürde, 1978 yılına kadar bildirilen olgu 38 iken 2010 yılında bu sayı 60 olmuştur. Endemik olmasına rağmen ülkemizden bildirilen olgu sayısı da birkaç tane ile sınırlıdır. Kostal hidatik kist nadir ve sıra dışı lokalizasyonlara yerleşimi nedeniyle ayrıcı tanıda kolaylıkla atlanabilir; yanlış veya geç tanı konulmasına neden olabilir. Hidatik kist özellikle endemik olarak bulunduğu bölgelerde tüm lezyonların ayırıcı tanısında mutlaka akılda tutulmalıdır.

Anahtar Sözcükler: Olağan dışı lokalizasyon, kaburga, kemik, hidatik, kist.

services are not insufficient (1). It has spread worldwide as a result of travel from these areas (2). Nearly all hydatid cysts are found in the liver or the lungs (1). Only $0.5 \%$ to $2 \%$ of all hydatid cyst cases demonstrate attachment to bone, and half of these are in the vertebrae (3). Costal residence of a hydatid cyst is extremely rare. In the literature, costal hydatid cyst has been reported in approximately 60 adult patients (4). Presently described is the case of a patient with a costal hydatid cyst, a presentation that is very unusual.
'Department of Thoracic Surgery, Health Sciences University, Konya Training and Research Hospital, Konya, Turkey

${ }^{2}$ Emergency and First Aid Program, Vocational School of Health Services KTO Karatay University, Konya, Turkey
'Sağlık Bilimleri Üniversitesi, Konya Eğitim ve Araştırma Hastanesi, Göğüs Cerrahisi Kliniği, Konya

${ }^{2}$ KTO Karatay Üniversitesi Sağlık Hizmetleri Meslek Yüksek Okulu, İlk ve Acil Yardım Programı, Konya

Submitted (Başvuru tarihi): 02.05.2017 Accepted (Kabul tarihi): 12.12.2017

Correspondence (iletişim): Mustafa Çalık, Department of Thoracic Surgery, Health Sciences University, Konya Training and Research Hospital, Konya, Turkey

e-mail:drmcalik@hotmail.com 


\section{CASE}

A 41 -year-old male patient presented at the clinic with left back pain. No anomaly was found in a physical examination or laboratory tests. His medical history included an operation for left lung hydatid cyst 20 years previously. A thorax computed tomography (CT) examination revealed a cystic mass $75 \times 40 \times 70 \mathrm{~mm}$ in size in the vertebra transverse process and in the left 9th and 10th ribs, with visible destruction (Figure 1). After all diagnostic tests were completed, he underwent surgery. A left-sided posterolateral thoracotomy was performed. An incision was made to the left hemithorax. The thorax was accessed and the cohesions were removed with obtuse and sharp dissection. A smooth-margined, 75x40x70-mm, lobulated lesion was identified adjacent to the T10 vertebra. The mass was protruding into the hemithorax and the adjacent soft tissue. It was also observed that the mass was a degenerated hydatid cyst when it was separated from the surrounding structures. Multiple germinative membranes were removed. The related area was resected with a 2 $\mathrm{cm}$ en bloc surgical border. The vertebra corpus and spinal cord were intact; no additional surgery was required for the vertebral corpus. The chest wall was closed primarily without any grafting. No perioperative complications developed. The diagnosis was verified with surgical exploration and histopathological evaluation. The patient was discharged on the postoperative sixth day without any complaint. Albendazole treatment of 10 $\mathrm{mg} / \mathrm{kg} /$ day was administered to the patient for 3 months. In 24 months of follow-up, he had no further recurrence or complications. Written informed consent was obtained from patient who participated in this study.

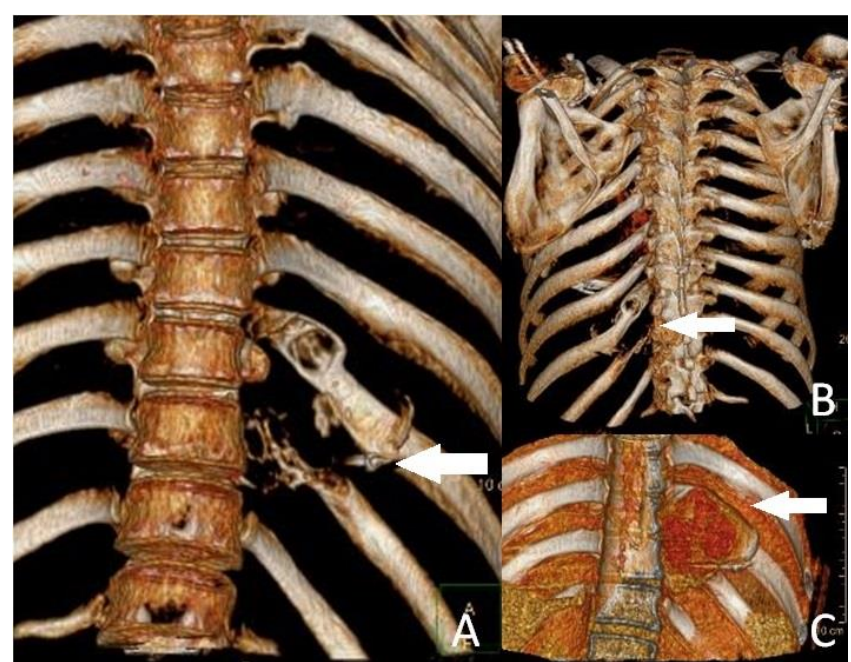

Figure 1: A three-dimensional computed tomography scan showing an expanding cystic mass in the 9th and10th ribs with destruction of the vertebral transverse process, seen in the $(A)$ anterior, $(B)$ posterior, and (C) anterior view with soft tissue (white arrow)

\section{DISCUSSION}

Although human beings have known of hydatid disease for 2000 years, it has been possible to understand the physiopathology and life cycle of the cyst only in the last 2 centuries. Despite being an ancient concern, it remains an important public health problem, especially in areas where it is endemic (1). Currently, there is virtually no country where hydatid cyst is not present due to increased travel and migration from endemic areas $(1,2)$. The eggs can remain viable for months in pastures, gardens, fomites, sand, or water, and may be consumed in foods such as vegetables, fruits, herbs, or contaminated water. While primarily a parasite of dogs, humans can accidentally become a host by swallowing the cystic form of the parasite. Cysts are not destroyed by the defense mechanisms of the human organism. Cysts formed in the duodenum may be distributed to any part of the body via the vena porta through hematogenous or lymphogenous routes. The liver and lungs, where hydatid cysts are most frequently resident, act as mechanical filters. This is why $90 \%$ of hydatid disease cases occur in these organs (1). The remaining $10 \%$ are found in tissues and organs, such as the spleen, pancreas, gallbladder, suprarenal gland, pelvis, seminal vesicle, heart, bone, breast, kidney, thyroid gland, and muscles with soft tissue (5). Although many hypotheses have been suggested for these rare localizations, their pathogenesis is not yet completely understood. The theory of shunt flow is perhaps the most accepted. Bone involvement is quite interesting when compared with other rare locations. Most often, localization is in compact bone containing calcium, which is porous, in contrast with soft tissue. It has been demonstrated by Dew (3) that hydatid cyst embryos localize in bone due to high vascularity, and invade other parts of bone and surrounding tissues.

Diagnosis can be made by evaluating the clinical, radiological, and laboratory data, as well as the anamnesis. The findings and symptoms of hydatid disease depend on the organ involved, localization in the organ and tissue, the effect on the adjacent tissue, rupture or complications, secondary infections, and immunological reactions. The most frequently seen early symptom is pain $(1,3)$. Left back pain was the initial complaint in our patient who was in compliance with literature. The medical history of this patient included an operation performed on the same side of the lungs 20 years earlier. Radiological monitoring methods are the first and most significant options. Laboratory tests have a limited effect in diagnosis. As in our case, views of hydatid cysts in rare localizations may 
lead to diagnostic problems, as they can be confused with benign or malign tumors, abscess, and other cysts. The preoperative diagnosis of our patient was neurogenic cyst. Costal hydatid cysts are differentiated from other bone hydatid cysts based on destruction in the rib or bone matrix and the rupture risk for surrounding tissues.

The most current treatment for bone hydatid cyst is still mostly based on the surgeon's opinion and experience, and typically moderate-to-poor quality evidence. Although the "best treatment" of bone hydatid cyst is still a matter of debate, management of these cases can be quite challenging due to the important problem of recurrence. There are numerous patient series in the literature describing hydatid cyst disease, whereas reports of recurrence and its frequency are limited to a few. In general, recurrence is seen at varying rates, beginning from the third month after the first operation to 20 years later (6). The highest recurrence rates were findings in $40 \%$ of the vertebrae (7), $17 \%$ of all bones (8), and $11.5 \%$ of the whole body. The World Health Organization (WHO) has no clear definition of relapse, recurrence, or re-infection of hydatid cyst. However, parameters have been defined in different series in the literature: primary hydatid cyst involvement except the liver and lung, liver cyst hydatid, difficult surgical site, multiple abdominal cysts, primary cyst larger than 7 to $10 \mathrm{~cm}$, and stage I and II hydatid cysts as graded by the $\mathrm{WHO}(6)$.

In a study evaluating 721 cases of osseous echinococcosis, recurrence was detected in 124 (17\%) patients within 2 years. All recurrences occurred at the same bone site and no new bone lesions were detected. In theory, the parasite may remain dormant in previously cured cysts causing no further harm. It may be considered a persistent infection or remission (8). Twenty years prior, our patient underwent surgery for a hydatid cyst in the lung parenchyma on the same side. A hydatid cyst grows 1 to $5 \mathrm{~mm}$ per year in the bone (7). Therefore, it would take some 15 years for a single cyst to reach a size of $75 \mathrm{~mm}$. There had been no change in the socioeconomic level or location of our patient over the previous 20 years and the same conditions were present that could lead to infection. Worldwide, the geographical distribution of the disease has not changed since 1930. Many authors have found similar distribution models, although there are now fewer reported cases (8). We accepted the patient as a case of primary hydatid cyst because of its size and due to the absence of other organ involvement, such as the liver, and 20 years having passed since the first operation.
Hypothetically, hydatid cyst is an eradicable disease; however, this has only been accomplished in small, developed island countries, like Iceland, New Zealand, Tasmania, Cyprus, and the Falkland Islands, as well as in limited areas in Argentina and Chile. In undeveloped or developing countries, such as the Mediterranean basin and the Middle East, animals retain their importance as sources of food, transportation, labor, and security. This makes control and eradication of the disease challenging, given the environmental conditions, hard-to-change cultural aspects, and human behaviors. It does not seem that this is likely to change in the near future in endemic areas. Therefore, the cheapest and the easiest approach are to work to prevent hydatid cyst from infecting humans (7).

There is a difference between costal and other bone hydatid cysts, due to the risk of cyst rupture due to damage to a rib or the bone matrix and the adjacent tissues. Costal hydatid cyst represents less than 1\% of all cases, yet while there were 38 cases reported in 1978, the total was 60 in 2010. Though it is endemic in Turkey, very few cases are reported in our country $(8,9)$. When possible, the ideal treatment to avoid radical surgical resection and recurrence is anthelmintic treatment, though the treatment period is still a matter of debate $(5,6,8)$.

\section{CONCLUSION}

Costal hydatid cyst is infrequently seen, even in areas like Turkey, where it is endemic. It can be easily neglected in a differential diagnosis due to its rarity, and particularly in unusual localizations, it may result in an incorrect or delayed diagnosis. Hydatid cyst should be kept in mind in the differential diagnosis of all lesions, especially in areas where it is endemic.

\section{CONFLICTS OF INTEREST}

None declared.

\section{AUTHOR CONTRIBUTIONS}

Concept - F.M.D., M.Ç., S.G.Ç., N.D., H.E.; Planning and Design - F.M.D., M.Ç., S.G.Ç., N.D., H.E.; Supervision - F.M.D., M.Ç., S.G.Ç., N.D., H.E.; Funding F.M.D., M.Ç., S.G.Ç., N.D., H.E.; Materials - M.Ç., S.G.Ç.; Data Collection and/or Processing - M.Ç., S.G.Ç.; Analysis and/or Interpretation - F.M.D., M.Ç., S.G.Ç., N.D., H.E.; Literature Review - M.Ç., S.G.Ç.; Writing - M.Ç., S.G.Ç.; Critical Review - F.M.D., M.Ç., S.G.Ç., N.D., H.E. 


\section{YAZAR KATKILARI}

Fikir - F.M.D., M.Ç., S.G.Ç., N.D., H.E.; Tasarım ve Dizayn - F.M.D., M.Ç., S.G.Ç., N.D., H.E.; Denetleme F.M.D., M.Ç., S.G.Ç., N.D., H.E.; Kaynaklar - F.M.D., M.Ç., S.G.Ç., N.D., H.E. Malzemeler - M.Ç., S.G.Ç.; Veri Toplama ve/veya İşleme - M.Ç., S.G.Ç.; Analiz ve/veya Yorum - F.M.D., M.Ç., S.G.Ç., N.D., H.E.; Literatür Taraması - M.Ç., S.G.Ç.; Yazıyı Yazan - M.Ç., S.G.Ç.; Eleştirel İnceleme - F.M.D., M.Ç., S.G.Ç., N.D., H.E.

\section{REFERENCES}

1. Calik SG, Calik M, Yesildag M, Esme H. Intramuscular hydatid cyst report of an unusual case. J Acad Emerg Med Case Rep 2016; 7:61-3. [CrossRef]

2. Budke CM, Deplazes P, Torgerson PR. Global socioeconomic impact of cystic echinococcosis. Emerg Infect Dis. 2006; 12:296-303. [CrossRef]

3. Kaloostian PE, Gokaslan ZL. Spinal hydatid disease: a multidisciplinary pathology. World Neurosurg 2015; 83:52-3. [CrossRef]
4. Demir HA, Demir S, Emir S, Kacar A, Tiryaki T. Primary hydatid cyst of the rib mimicking chest wall tumor: a case report. J Pediatr Surg 2010; 45:2247-9. [CrossRef]

5. Safioleas $M$, Nikiteas $N$, Stamatakos M, Safioleas C, Manti $\mathrm{CH}$, Revenas $\mathrm{C}$, et al. Echinococcal cyst of the subcutaneous tissue: a rare case report. Parasitol Int 2008; 57:236-8. [CrossRefl

6. Velasco-Tirado $V$, Romero-Alegría Á, Belhassen-García M, Alonso-Sardón M, Esteban-Velasco C, López-Bernús $A$, et Al. Recurrence of cystic echinococcosis in an endemic area: a retrospective study. BMC Infect Dis 2017; 17:455. [CrossRef]

7. Çalık, M., Çalık, S.G., Esme, H. Vertebral hydatid disease: White cancer. Respir Case Rep 2017; 6:103-6. [CrossRef]

8. Steinmetz S, Racloz G, Stern R, Dominguez D, Al-Mayahi $M$, Schibler $M$, et al. Treatment challenges associated with bone echinococcosis. J Antimicrob Chemother 2014; 69:821-6. [CrossRef]

9. Karaoğlanoğlu N, Gorguner M, Eroglu A. Hydatid disease of rib. Ann Thorac Surg 2001; 71:372-3. [CrossRef] 